\title{
INTERDIGITATED FLOW CHANNEL ON A PROTON EXCHANGE MEMBRANE FUEL CELL INVESTIGATED USING THE RESPONSE SURFACE METHODOLOGY
}

\begin{abstract}
Summary
Performance of the proton exchange membrane (PEM) fuel cell depends on the operating pressure, operating temperature, stoichiometric ratio of reactant gases, relative humidity, and rib width-to-channel width ratio $(\mathrm{R}: \mathrm{C})$, shape of the flow channel, and the number of passes on the flow channel. The effect of pressure, temperature, inlet reactant mass flow rate and rib width-to-channel width ratios of $1: 1,1: 2,2: 1$, and 2:2 on the power density of a PEM fuel cell with interdigitated flow channel of $25 \mathrm{~cm}^{2}$ active area of was considered in this study. The response surface methodology was used for optimizing the four above mentioned parameters to find the optimum power density of the PEM fuel cell. The analysis of variance (ANOVA) was used to find the contribution of each parameter to the performance of the PEM fuel cell. Further, numerical results were compared with the experimental validation of the PEM fuel cell. Numerical results of power densities of interdigitated flow channel with $\mathrm{R}: \mathrm{C}$ ratios of $1: 1,1: 2,2: 1$, and $2: 2$ were found to be $0.272,0.292,0.267$, and $0.281 \mathrm{~W} / \mathrm{cm}^{2}$ and the corresponding experimental results of power density were $0.261,0.266$, 0.254 , and $0.264 \mathrm{~W} / \mathrm{cm}^{2}$, respectively.
\end{abstract}

Key words: $\quad$ Optimization; PEM fuel cell; response surface methodology; computational fluid dynamics; interdigitated flow channel; rib width-to-channel width ratio.

\section{Introduction}

A Proton Exchange Membrane (PEM) fuel cell is an eco-friendly power source which is suitable for powering both portable devices and mobile applications due to their high energy density and lower operating temperature range [1]. It is a high efficiency tool used to generate clean renewable energy. In this quiet power generation system, many parameters, such as operating and design parameters could have either major or minor roles in the performance of the PEM fuel cell [2]. Imdat Taymaz and Elif Eker Kahveci optimised various operation parameters for the performance of the PEM fuel cell using the Response Surface Methodology (RSM). The authors concluded that the hydrogen flow rate, oxygen flow rate, humidification temperature, and cell temperature were the main parameters to affect the performance of the PEM fuel cell. They also found that the maximum power density was 
$241.977 \mathrm{~mW} / \mathrm{cm}^{2}$ [3]. Kanani et al investigated the effects of operating conditions (cathode and anode stoichiometry, gas inlet temperature, and cathode relative humidity) for the serpentine flow channel on the performance of the PEM fuel cell by using the design of experiments. The response surface methodology was used to model the relationship between the cell potential and power with various operating input parameters. The results revealed that the low and the high stoichiometry of reactant on the anode and the cathode result in the minimum cell power. On the other hand, the optimum ranges of stoichiometry of fuel and oxidants on the anode and the cathode lead to the best performance [4].

A three-dimensional computational fluid dynamics (CFD) model was used by Jaruwasupant and Khunatorn to investigate the effects of serpentine flow channel curvature and length, pressure drop, and velocity distribution on the performance of the PEM fuel cell. The result revealed that the sharp curve was the best configuration because it has non-uniform flow distribution with low velocity and high pressure drop during the reactant flow [5]. The effect of gas flow fields on the performance of a fuel cell with various flow channel designs, such as single and multiple channel serpentine, parallel channels, pin type flow field, interdigitated and spiral type flow channel (with $23.5 \mathrm{~cm}^{2}$ of the PEM fuel cell effective area), was investigated experimentally by Liu et al. The results showed that the single serpentine flow channel design gave the best performance of all the flow channel designs that exist [6]. Cheng et al studied the influence of interaction effects of design parameters on the performance of a single $25 \mathrm{~cm}^{2}$ PEM fuel cell by using the Taguchi technique and CFD. The factors considered in this study include the flow channel design, operating temperature, and the relative humidity of the reactant on the cathode. The results revealed that the most significant effect on the polarization curve is exerted by the flow channel design, followed by the cell temperature and the relative humidity of the cathode gas mixture [7]. Iranzo et al analysed a CFD model with $50 \mathrm{~cm}^{2}$ of active area with parallel and serpentine flow fields using the Ansys fluent software to enhance the performance of the PEM fuel cell. The result showed that the serpentine flow field performed better than the parallel flow field; in addition, it was concluded that the results of a CFD fuel cell model cannot be trusted without being experimentally validated. In the serpentine flow field, it was observed that the reactant humidification enhances the performance as it prevents the membrane electrode assembly from drying out [8]. Optimisation of various parameters of interdigitated flow channel with $25 \mathrm{~cm}^{2}$ of active area of the PEM fuel cell was carried out by Lakshminarayanan et al [9]. The results revealed that the landing-to-channel width ratio $(\mathrm{L}: \mathrm{C}-1: 1)$ has the maximum influence on the PEM fuel cell performance and produces power density of $0.4086 \mathrm{~W} / \mathrm{cm}^{2}$.

The performance of a PEM fuel cell was improved in the study carried out by Lakshminarayanan and Karthikeyan [10]. The authors investigated the combined effect of design and operating parameters of the serpentine and the interdigitated flow channel with $25 \mathrm{~cm}^{2}$ of active area using the optimization technique and CFD. The results revealed that the peak power density of interdigitated flow channel with the landing-to-channel width (L:C) ratio of 1:2 proved to be better than that of the serpentine flow channel with the L:C ratio of $1: 2$. The performance of the PEM fuel cell had been influenced by operating parameters (pressure, cell temperature, relative humidity, and the stoichiometric ratio of reactants) and design parameters (rib-to-channel width ratios, depth of the channel, and number of passes on the flow channel).

Even though a large number of studies found in literature deal with the effect of flow field design and operating parameters on the performance of PEM fuel cells, this study differs from them by the fact that the PEM fuel cell performance has been studied both numerically and experimentally with respect to various rib-to-channel width $\operatorname{ratios}(1: 1,1: 2,2: 1$, and 2:2) 
and to various operating parameters (operating pressure, temperature and stoichiometric ratio of reactant mass flow rate) on the interdigitated flow channel with $25 \mathrm{~cm}^{2}$ active area of PEM fuel cell.

\section{Model development}

The modelling and analysis were done using the Creo parametric 2.0 software and the CFD Fluent 14.0 software, respectively. The Creo Parametric 2.0 and CFD software packages were used to create a three-dimensional (3-D) model and simulation of the PEM fuel cell. The response surface methodology was applied to optimize the operating and design parameters of the PEM fuel cell. The analysis of variance (ANOVA) was used to compute the effects of various parameters on the fuel cell maximum power density as well as their contributions to it. Using this approach, it is possible to reduce the number of experiments and save time.

A numerical investigation into the PEM fuel cell performance in an active area of $25 \mathrm{~cm}^{2}$ with various rib-to-channel width ratios (R:C - 1:1, 1:2, 2:1, and 2:2) on the interdigitated flow field was carried out using various values of operating pressure and operating temperature. The CFD software was used for the numerical investigation and the obtained values were validated experimentally.

\subsection{Numerical simulation}

The numerical simulation consisted of three phases. In the first phase, the required 3-D PEM fuel cell with various R:C ratios was modelled using the Creo 2.0 tool. Threedimensional geometry in the Para solid format was imported to the ICEM-14.0 tool for finite volume discretisation. Discretisation is a process in which a single PEM fuel cell domain is divided into a number of small finite volumes referred to as meshing. The necessary boundary conditions including the properties of flow fields, gas diffusion layers (GDL), catalyst, membrane electrode on both the cathode side and the anode side were defined together with the terminals with flow rates of hydrogen and oxygen. The temperature of the reactants and oxidants and the operating pressure were also defined. In the second phase, the flow through the three-dimensional PEM fuel cell was defined by solving the appropriate governing equations, namely the equations for conservation of mass, conservation of momentum, conservation of energy, conservation of current, and conservation of species as well as electro-chemical equations. These governing equations were solved using the CFD Fluent 14.0 software code for ensuring better convergence. In the third phase, the numerical results predicted by the CFD code were post-processed in order to get the values of the current density, the power density, and the hydrogen, oxygen and water concentrations in the PEM fuel cell required for analysing the performance.

\subsection{Geometric modelling}

The modelling of the PEM fuel cell was done by creating seven parts, i.e. central membrane electrolyte (Nafion), catalyst layers (2), gas diffusion layers (2) and flow fields (2), which were assembled to form a single part in the Creo 2.0 software. Figure 1(a) shows a view of the PEM fuel cell model. Different configurations on the interdigitated flow field were modelled using the Creo 2.0 tool for $25 \mathrm{~cm}^{2}$ active area of the PEM fuel cell, as shown in Figure 1 (b). Various geometric models (rib width-to-channel width of 1:1, 1:2, 2:1, and $2: 2$ ) form a basis for creating a mesh. The assignments of zones for various parts were done by Workbench 14.0. The dimensions of the components and the zone type are given in Table 1. 
V. Lakshminarayanan, P. Velmurugan,

P. Karthikeyan

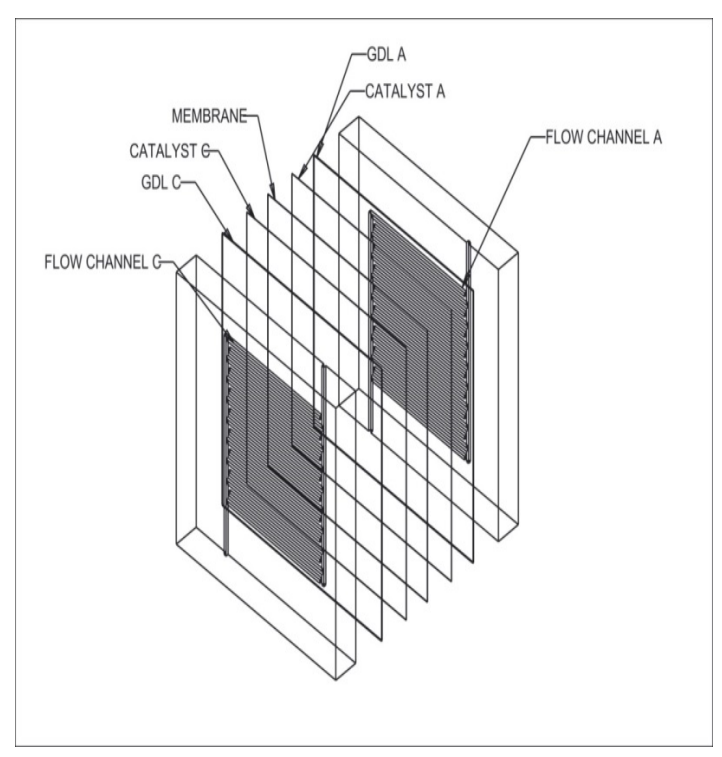

Interdigitated Flow Channel on a Proton Exchange Membrane Fuel Cell Investigated Using the Response Surface Methodology

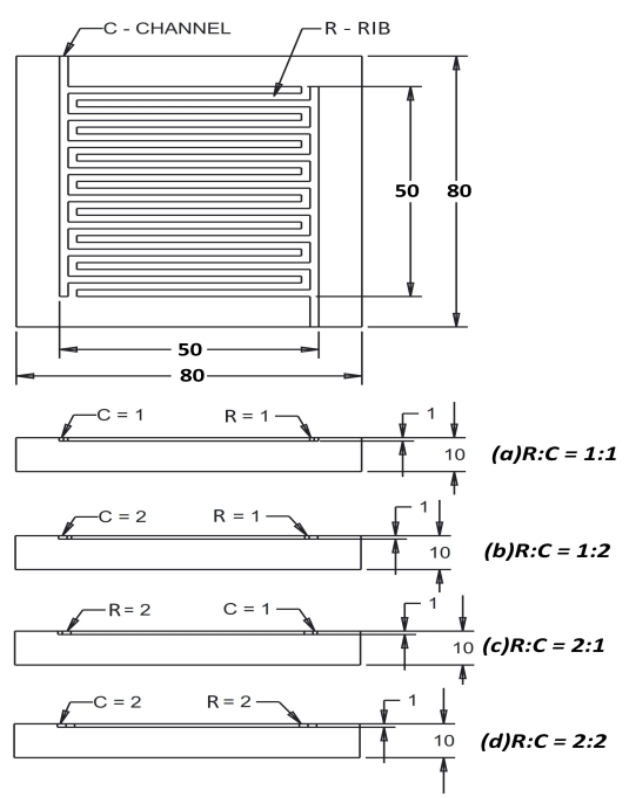

Fig. 1 (a) A view of the PEM fuel cell and flow fields as a single part (b) Interdigitated flow field with $\mathrm{R}: \mathrm{C}$ ratios of 1:1, 1:2, 2:1, and 2:2

Table 1 Dimensions of a $25 \mathrm{~cm}^{2}$ PEM fuel cell.

\begin{tabular}{|c|l|c|c|c|c|}
\hline S.No & \multicolumn{1}{|c|}{ Part Name } & $\begin{array}{c}\text { Width } \\
(\mathrm{mm})\end{array}$ & $\begin{array}{c}\text { Length } \\
(\mathrm{mm})\end{array}$ & $\begin{array}{c}\text { Thickness } \\
(\mathrm{mm})\end{array}$ & Zone type \\
\hline 1 & Catalyst - anode \& cathode & 50 & 50 & 0.08 & Fluid \\
\hline 2 & Current collector - anode \& cathode & 80 & 80 & 10 & Solid \\
\hline 3 & Membrane & 50 & 50 & 0.127 & Fluid \\
\hline 4 & GDL - anode \& cathode & 50 & 50 & 0.3 & Fluid \\
\hline
\end{tabular}

\subsection{Discretisation}

A grid for the PEM fuel cell model was generated by ICEM- 14.0, a commercially available CFD tool for meshing. As the available geometry has the thickness varying from some microns to millimetres, the generation of a mesh as a single whole domain is quite complex. Therefore, each part in the PEM fuel cell model was meshed individually using the blocking method in order to have proper control over the mesh size suitable for producing pure hexahedral elements. These elements make it possible to capture the hydraulic and thermal boundary layers along with electro-chemical reactions. Except the current collectors, all the parts in the PEM fuel cell are defined as a fluid zone, while the current collectors on the anode and the cathode side are defined as solid in the cell zone condition. The fluid-fluid interface was given between the membrane electrolyte, catalyst layer, gas diffusion layer, and the flow field on either side of the cell, whereas the solid-fluid interface condition was assigned between the current collectors and the flow channel on both sides of the PEM fuel cell. The grid-independent study was conducted for various $\mathrm{R}: \mathrm{C}$ ratios $(1: 1,1: 2,2: 1$, and 2:2) of $25 \mathrm{~cm}^{2}$ active area of interdigitated flow fields.

\subsection{Governing Equations}

The simulation was carried out by solving simultaneous equations, such as equations for conservation of mass, momentum, energy, species concentration, the Joule heating reaction, the Butler-Volmer equation, and the Nernst equation, in order to obtain the reaction kinetics of the PEM fuel cell. The assumptions made while modelling the PEM fuel cell were steady state, laminar and incompressible flow with isothermal, homogeneous material properties, 
adoption of Darcy's law with negligence of gravitational field effect and contact resistance. Thermo-physical properties were constant and the porous GDL, two catalyst layers used in the anode \& cathode side and the membrane were an isotropic in nature. The following equations (1-16) were involved in the model mentioned above.

Continuity equation

$$
\frac{\partial \rho}{\partial t}+\nabla \cdot(\partial v)=0
$$

Conservation of momentum

$$
\frac{\partial(\rho v)}{\partial t}+\nabla \cdot(\rho v v)=-\nabla \rho+\nabla \cdot\left(\mu^{e f f} \nabla v\right)+S_{m}
$$

Conservation of energy

$$
\begin{aligned}
& \left(\rho C_{p}\right)_{\text {eff }} \frac{\partial T}{\partial t}+\left(\rho C_{p}\right)_{e f f}(v \cdot \nabla T)=\nabla\left(k_{\text {eff }} \nabla T\right)+S_{e} \\
& \left(\rho C_{p}\right)_{\text {eff }}=(1-\varepsilon) \rho_{s} C_{p, s}+\varepsilon \rho C_{p}, \quad k_{\text {eff }}=-2 k_{s}+\left[\frac{\varepsilon}{2 k_{s}+k}+\frac{1-\varepsilon}{3 k_{s}}\right] .
\end{aligned}
$$

Condensation or evaporation of water vapour/liquid water leads to heat generation or heat absorption in the catalyst layer.

$$
S_{e}=|j|\left[\left|\Delta V_{a c t}\right|-\frac{T \Delta S}{n F}\right]+\left(\frac{i_{e}^{2}}{k_{s}^{e f f}}+\frac{i_{m}^{2}}{k_{m}^{e f f}}\right)-\sigma A_{f g}\left(x_{s a t}-x_{H_{2} O(g)}\right) \Delta h_{f g}
$$

Current flow through the solid parts of the GDL

$$
S_{e}=\frac{i_{e}^{2}}{k_{s}^{e f f}}-\sigma A_{f g}\left(x_{s a t}-x_{H_{2} O(g)}\right) \Delta h_{f g}
$$

Ohmic losses in the membrane (transport of ions)

$$
S_{e}=\frac{i_{m}^{2}}{k_{m}}
$$

Darcy's law through porous media

$$
S_{m}=-\frac{\mu}{K} \varepsilon v
$$

Conservation of species

$$
\begin{aligned}
& \frac{\partial\left(\varepsilon p x_{i}\right)}{\partial t}+\nabla\left(v \varepsilon \rho_{i}\right)=\nabla \cdot\left(\rho D_{i}^{e f f} \nabla x_{i}\right)+S_{s, i} \\
& S_{s, H_{2}}=-j_{a} \frac{M_{H_{2}}}{2 F}-\text { Rate of hydrogen consumption in the anode catalyst layer } \\
& S_{s, O_{2}}=-j_{c} \frac{M_{O_{2}}}{2 F}-\text { Rate of hydrogen consumption in the cathode catalyst layer } \\
& S_{s, H_{2} O(I)}=-j_{c} \frac{M_{\mathrm{H}_{2} \mathrm{O}}}{2 F}-\sigma A_{f g}\left(x_{s a t}-x_{\mathrm{H}_{2} \mathrm{O}(g)}\right) \Delta h_{f g} \text { - Rate of liquid vapour formation } \\
& S_{s, \mathrm{H}_{2} \mathrm{O}(\mathrm{g})}=\sigma A_{f g}\left(x_{s a t}-x_{\mathrm{H}_{2} \mathrm{O}(g)}\right) \text { - Rate of water vapour formation }
\end{aligned}
$$


The Stefan-Maxwell equation for multi-component species - Mole fraction of the components

$$
\frac{\mathrm{d} x_{i}}{\mathrm{~d} z}=R T \sum \frac{x_{i} N_{j}-x_{j} N_{i}}{P D_{i j}}
$$

Conservation of charge

$$
\begin{aligned}
& \nabla \cdot\left(k_{s}^{e f f} \nabla \phi_{s}\right)=S_{\phi s}-\text { Electric current } \\
& \nabla \cdot\left(k_{m}^{e f f} \nabla \phi_{m}\right)=S_{\phi m}-\text { Ionic current } \\
& S_{\phi s}=-j_{a} \text { and } S_{\phi m}=j_{a i} \text { - At the anode catalyst layer } \\
& S_{\phi s}=-j_{c} \text { and } S_{\phi m}=-j_{c i} \text { - At the cathode catalyst layer }
\end{aligned}
$$

Electrochemical equation

$$
V_{\text {cell }}=V_{\text {rev }}-\frac{R T}{\alpha F} \ln \left(\frac{i}{i_{o}}\right)-\left(r_{\text {ele }}-r_{\text {ion }}\right)-\frac{R T}{n F} \ln \left(1-\frac{i}{i_{\text {lim }}}\right)
$$

The Nernst equation for reversible cell potential

$$
V_{\text {rev }}=V_{\text {rev }}^{o}+\frac{R T}{n F} \ln \left(\frac{P_{\mathrm{H}_{2}} P_{\mathrm{O}_{2}}^{0.5}}{P_{\mathrm{H}_{2} \mathrm{O}}}\right)
$$

The Butler-Volmer equation for activation over potential

$$
\begin{aligned}
& \Delta V_{a c t}=\frac{R T}{n F} \ln \left(\frac{i}{i_{o}}\right) \\
& i_{o}=i_{o}^{r e f} a_{c} L_{c}\left(\frac{P_{r}}{P_{r}^{r e f}}\right)^{\gamma} \exp \left[-\frac{E_{c}}{R T}\left(1-\frac{T}{T_{r e f}}\right)\right]
\end{aligned}
$$

Concentration over potential

$$
\begin{aligned}
& \Delta V_{\text {conc }}=\frac{R T}{n F} \ln \left(1-\frac{i}{i_{\text {lim }}}\right) \\
& i_{\text {lim }}=\frac{n F D C_{B}}{\delta}
\end{aligned}
$$

Empirical equation for the membrane conductivity as a function of the membrane water content and temperature

$$
\begin{aligned}
& \sigma=(0.005139 \lambda-0.00326) \exp \left[1268\left(\frac{1}{303}-\frac{1}{T}\right)\right] \\
& \lambda=0.043+17.8 a-39.85 a^{2}+36 a^{3} \quad 0<a<1 \\
& \lambda=14+1.4(a-1) \quad 0<a \leq 3 \\
& a=\frac{x_{\mathrm{H}_{2} \mathrm{O}} P}{P_{\text {sat }}}
\end{aligned}
$$


Water transport mechanism of the membrane

(a) Diffusion due to concentration difference:

$$
\begin{aligned}
& N_{H_{2} O, \text { diff }}=D_{w} \frac{\Delta C}{\Delta Z} \\
& D_{w}=D_{\lambda} \exp \left(2416\left(\frac{1}{303}-\frac{1}{T_{c}}\right)\right) \\
& D_{\lambda}=\left(\begin{array}{l}
10^{-6}, \lambda<2 \\
10^{-6}(1+2(\lambda+2)), 2 \leq \lambda \leq 3 \\
10^{-6}(3-1.67(\lambda-3)), 2 \leq \lambda \leq 4.5 \\
1.25 \times 10^{-6}, \lambda \geq 4.5
\end{array}\right)
\end{aligned}
$$

(b) Electro-osmotic drag

$$
\begin{aligned}
& N_{H_{2} O, \text { drag }}=n_{d} \frac{1}{F} \\
& n_{d}=0.0029 \lambda^{2}+0.05 \lambda-3.4 \times 10^{-19}
\end{aligned}
$$

(c) Pressure difference

$$
N_{H_{2} O, P_{r}}=K_{p} \frac{\Delta P}{\Delta Z}
$$

The boundary conditions and their corresponding values are listed in Table 2. The electrochemical properties of the PEM fuel cell are given in Table 3 according to Hyung Soon Kim et al [12] and Behzad Osanloo et al [13].

Theoretical calculation of the mass flow rate of reactants

Mass flow rate of hydrogen $\left(\mathrm{mH}_{2}\right)=\left(\mathrm{I}^{*} \mathrm{MH}_{2} / 2 \mathrm{~F}\right)$

$$
=(1.65 \times 25 \times 2 \times 10-3) /(2 \times 96485)=4.2753 \times 10^{-7} \mathrm{~kg} / \mathrm{sec}
$$

Mass flow rate of oxygen $\left(\mathrm{mO}_{2}\right)=\left(\mathrm{I}^{*} \mathrm{MO}_{2} / 4 \mathrm{~F}\right)$

$$
=(1.65 \times 25 \times 32 \times 10-3) /(4 \times 96485)=3.4202 \times 10^{-6} \mathrm{~kg} / \mathrm{sec}
$$

Table 2 Boundary conditions of a $25 \mathrm{~cm}^{2}$ PEM fuel cell.

\begin{tabular}{|c|l|l|l|}
\hline S.No & Boundary conditions & \multicolumn{1}{c|}{ Type } & \multicolumn{1}{c|}{ Value } \\
\hline 1 & Anode inlet & Mass flow inlet & $4.2753 \times 10^{-7}$ \\
\hline 2 & Cathode inlet & Mass flow inlet & $3.4202 \times 10^{-6}$ \\
\hline 3 & Anode outlet & Pressure outlet & 2 bar \\
\hline 4 & Cathode outlet & Pressure outlet & 2 bar \\
\hline 5 & Anode and cathode wall terminals & Wall & No slip \\
\hline
\end{tabular}


Table 3 Electrochemical properties of the PEM fuel cell

\begin{tabular}{|c|l|l|}
\hline S. No & \multicolumn{1}{|c|}{ Properties } & \multicolumn{1}{|c|}{ Value } \\
\hline 1 & Anode reference exchange current density $\left(\mathrm{A} / \mathrm{m}^{2}\right)$ & 3300 \\
\hline 2 & Cathode reference current density $\left(\mathrm{A} / \mathrm{m}^{2}\right)$ & $7.75 \mathrm{E}-04$ \\
\hline 3 & Anode reference concentration $\left(\mathrm{kmol} / \mathrm{m}^{3}\right)$ & 0.0488 \\
\hline 4 & Cathode reference concentration $\left(\mathrm{kmol} / \mathrm{m}^{3}\right)$ & 0.0488 \\
\hline 5 & Anode transfer coefficient & 0.5 \\
\hline 6 & Cathode transfer coefficient & 1 \\
\hline 7 & Reference diffusivity of $\mathrm{H}_{2}\left(\mathrm{~m}^{2} / \mathrm{s}\right)$ & $1.1 \mathrm{e}-4$ \\
\hline 8 & Reference diffusivity of $\mathrm{O}_{2}\left(\mathrm{~m}^{2} / \mathrm{s}\right)$ & $3.23 \mathrm{e}-5$ \\
\hline 9 & Reference diffusivity of $\mathrm{H}_{2} \mathrm{O}\left(\mathrm{m}^{2} / \mathrm{s}\right)$ & $7.35 \mathrm{e}-5$ \\
\hline
\end{tabular}

\section{Experimental setup}

A computer (V.5.22 software package) interfaced fuel cell test equipment Bio-Logic FCT-50S (Fuel Cell Test station) was used for conducting experimental analysis. For the experimental analysis, a commercially available gas diffusion electrode (GDE) sheet (PaxiTech from France) was used. The GDE has carbon paper as its GDL or diffusion medium and $40 \% \mathrm{Pt} / \mathrm{C}$ as a catalyst with a loading of $0.5 \mathrm{mg} / \mathrm{cm}^{2}$. The required size of the membrane (Nafion 115) was sandwiched with the GDE on both sides by hot pressing using the pressure of $50 \mathrm{~kg} / \mathrm{cm}^{2}$ and the temperature of $130^{\circ} \mathrm{C}$ for $3 \mathrm{~min}$ in the preparation of the membrane electrode assembly (MEA). Highly purified hydrogen (99.99\%) and pure oxygen were used as a fuel and an oxidant, respectively. The gold coated copper plates were used for the current collector on the anode and the cathode side. The MEA was humidified properly and it was confirmed that it worked at its peak power value. In order to humidify the MEA, an activation procedure was followed by the application of the current pulse and voltage pulse programs. The potential can be set to an absolute value or can be set relative to the initial voltage at the beginning of the procedure.

In the current pulse activation procedure, the current scan experiment sweeps the current applied to the fuel cell from zero to a set value in a predetermined increment to reach the final set value of the current. Thus, the peak power density and the limiting voltage of the PEM fuel cell can be achieved. A voltage pulse involves stepping up the voltage of the PEM fuel cell. The potential steps can be set to an absolute value (E) at the beginning of the experiment. The measurement of the current response to an applied potential step was controlled by potential techniques. In order to properly humidify the MEA, which has been dried out during the hot pressing stage, a conditioning or activation procedure is used first. We carried out a large number of experimental trails in our laboratory for conditioning the MEA to enhance the proton conduction on the membrane from the constant current, constant voltage, and constant power modes by using a cyclic looping process.

Experimental validation of the $25 \mathrm{~cm}^{2}$ PEM fuel cell with various rib-to-channel width ratios of interdigitated flow fields was carried out to assess the reliability of numerical results. In the present study, operating pressure of 2 bar, cell temperature of $343 \mathrm{~K}$ and the inlet mass flow rate of the reactants which is four times the theoretical mass flow rate have been considered. Karthikeyan et al carried out an experimental investigation into $25 \mathrm{~cm}^{2}$ PEM fuel cell performance for $\mathrm{R}: \mathrm{C}$ ratios of 1:1 and 2:2 of interdigitated flow fields [11].

\section{Results and Discussions}

Table 4 shows the values of peak power density and current density for a combination of design and operating parameters with interdigitated flow fields. The rib-to-channel width 
Interdigitated Flow Channel on a Proton Exchange

Membrane Fuel Cell Investigated Using

V. Lakshminarayanan, P. Velmurugan, the Response Surface Methodology

ratio of 1:1 for interdigitated flow field has shown maximum current and power densities of $0.574 \mathrm{~A} / \mathrm{cm}^{2}$ and $0.272 \mathrm{~W} / \mathrm{cm}^{2}$, respectively.

Table 4 Peak power density with various R:C ratios of interdigitated flow fields on a $25 \mathrm{~cm}^{2}$ PEM fuel cell

\begin{tabular}{|c|c|c|c|c|c|c|c|c|c|c|}
\hline \multicolumn{3}{|c|}{$\begin{array}{l}\text { Operating } \\
\text { condition }\end{array}$} & \multicolumn{2}{|c|}{$\mathrm{R}: \mathrm{C}-1: 1$} & \multicolumn{2}{|c|}{$\mathrm{R}: \mathrm{C}-1: 2$} & \multicolumn{2}{|c|}{$\mathrm{R}: \mathrm{C}-2: 1$} & \multicolumn{2}{|c|}{$\mathrm{R}: \mathrm{C}-2: 2$} \\
\hline $\begin{array}{l}0 \\
\vdots \\
0 \\
0 \\
0 \\
0\end{array}$ & 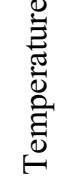 & $\begin{array}{l}\text { St. } \\
\text { Ratio }\end{array}$ & $\begin{array}{l}\text { Current } \\
\text { Density } \\
\left(\mathrm{A} / \mathrm{cm}^{2}\right)\end{array}$ & $\begin{array}{c}\text { Power } \\
\text { Density } \\
\left(\mathrm{W} / \mathrm{cm}^{2}\right)\end{array}$ & $\begin{array}{l}\text { Current } \\
\text { Density } \\
\left(\mathrm{A} / \mathrm{cm}^{2}\right)\end{array}$ & $\begin{array}{c}\text { Power } \\
\text { Density } \\
\left(\mathrm{W} / \mathrm{cm}^{2}\right)\end{array}$ & $\begin{array}{l}\text { Current } \\
\text { Density } \\
\left(\mathrm{A} / \mathrm{cm}^{2}\right)\end{array}$ & $\begin{array}{c}\text { Power } \\
\text { Density } \\
\left(\mathrm{W} / \mathrm{cm}^{2}\right)\end{array}$ & $\begin{array}{l}\text { Current } \\
\text { Density } \\
\left(\mathrm{A} / \mathrm{cm}^{2}\right)\end{array}$ & $\begin{array}{c}\text { Power } \\
\text { Density } \\
\left(\mathrm{W} / \mathrm{cm}^{2}\right)\end{array}$ \\
\hline 1 & 323 & 4 & 0.421 & 0.200 & 0.392 & 0.186 & 0.458 & 0.218 & 0.466 & 0.221 \\
\hline 1 & 343 & 3 & 0.240 & 0.108 & 0.319 & 0.135 & 0.189 & 0.085 & 0.188 & 0.089 \\
\hline 1 & 343 & 4 & 0.275 & 0.124 & 0.342 & 0.145 & 0.208 & 0.088 & 0.204 & 0.092 \\
\hline 2 & 343 & 3 & 0.591 & 0.266 & 0.632 & 0.284 & 0.548 & 0.260 & 0.583 & 0.263 \\
\hline 2 & 323 & 3 & 0.483 & 0.229 & 0.633 & 0.253 & 0.547 & 0.246 & 0.487 & 0.231 \\
\hline 2 & 333 & 3.5 & 0.561 & 0.252 & 0.606 & 0.272 & 0.612 & 0.260 & 0.527 & 0.250 \\
\hline 1.5 & 333 & 3 & 0.505 & 0.240 & 0.579 & 0.260 & 0.586 & 0.234 & 0.540 & 0.243 \\
\hline 1 & 323 & 3 & 0.485 & 0.218 & 0.578 & 0.260 & 0.444 & 0.211 & 0.510 & 0.217 \\
\hline 1.5 & 343 & 3.5 & 0.576 & 0.245 & 0.617 & 0.262 & 0.515 & 0.219 & 0.548 & 0.233 \\
\hline 1.5 & 333 & 3.5 & 0.549 & 0.247 & 0.586 & 0.263 & 0.473 & 0.236 & 0.459 & 0.229 \\
\hline 2 & 343 & 4 & 0.574 & 0.272 & 0.615 & 0.292 & 0.627 & 0.267 & 0.662 & 0.281 \\
\hline 1.5 & 323 & 3.5 & 0.484 & 0.230 & 0.387 & 0.184 & 0.463 & 0.220 & 0.440 & 0.209 \\
\hline 2 & 323 & 4 & 0.505 & 0.240 & 0.420 & 0.189 & 0.582 & 0.248 & 0.512 & 0.217 \\
\hline 1 & 333 & 3.5 & 0.513 & 0.231 & 0.639 & 0.271 & 0.495 & 0.211 & 0.522 & 0.222 \\
\hline 1.5 & 333 & 4 & 0.560 & 0.252 & 0.591 & 0.266 & 0.508 & 0.241 & 0.456 & 0.217 \\
\hline
\end{tabular}

Similarly, R:C ratios of $1: 2$ and $2: 1$ have shown the maximum current density of $0.615 \mathrm{~A} / \mathrm{cm}^{2}$ and $0.627 \mathrm{~A} / \mathrm{cm}^{2}$ and the corresponding power density of $0.292 \mathrm{~W} / \mathrm{cm}^{2}$ and $0.267 \mathrm{~W} / \mathrm{cm}^{2}$, respectively. For the rib-to-channel width ratio of $2: 2$, the maximum current density was $0.662 \mathrm{~A} / \mathrm{cm}^{2}$ and the power density was $0.281 \mathrm{~W} / \mathrm{cm}^{2}$. Hence, the operating pressure of 2 bar, the cell temperature of $343 \mathrm{~K}$ and four stoichiometric ratios of gases yield the maximum performance compared with various values of pressure and cell temperature.

Figure 2 shows the power density as a function of pressure temperature and stoichiometric ratio. Figure 2(a) shows clearly that as the pressure and the temperature increase, the power density also increases. Figure 2(b) shows the power density as a function of pressure and stoichiometric ratio of the reactants. It is clearly evident that as the pressure increases, the power density also increases; however, as the stoichiometric ratio increases, the power density increases to a certain level, then it decreases gradually even though the stoichiometric ratio increases, see Figure 2(c). The experimental performance of various ribsto-channel width ratios of interdigitated flow field is shown in Figure 3. The experimental studies showed that the peak power density of the interdigitated flow field of R:C ratios of $1: 1,1: 2,2: 1$, and $2: 2$ were $0.261 \mathrm{~W} / \mathrm{cm}^{2}, 0.266 \mathrm{~W} / \mathrm{cm}^{2}, 0.254 \mathrm{~W} / \mathrm{cm}^{2}$, and $0.264 \mathrm{~W} / \mathrm{cm}^{2}$, respectively, as shown in Table 5. The corresponding current densities were $0.580 \mathrm{~A} / \mathrm{cm}^{2}$, $0.592 \mathrm{~A} / \mathrm{cm}^{2}, 0.535 \mathrm{~A} / \mathrm{cm}^{2}$, and $0.588 \mathrm{~A} / \mathrm{cm}^{2}$, respectively. It was also observed that the maximum peak power performance of the interdigitated flow field was $0.266 \mathrm{~W} / \mathrm{cm}^{2}$ for R:C$1: 2$ and the minimum of $0.254 \mathrm{~W} / \mathrm{cm}^{2}$ was observed for $\mathrm{R}: \mathrm{C}-2: 1$, with a $4.72 \%$ deviation. 
(a)

QP X FS EFO TUZ !wt!QSFTTVSF BOE !UFN QFSBUVSF

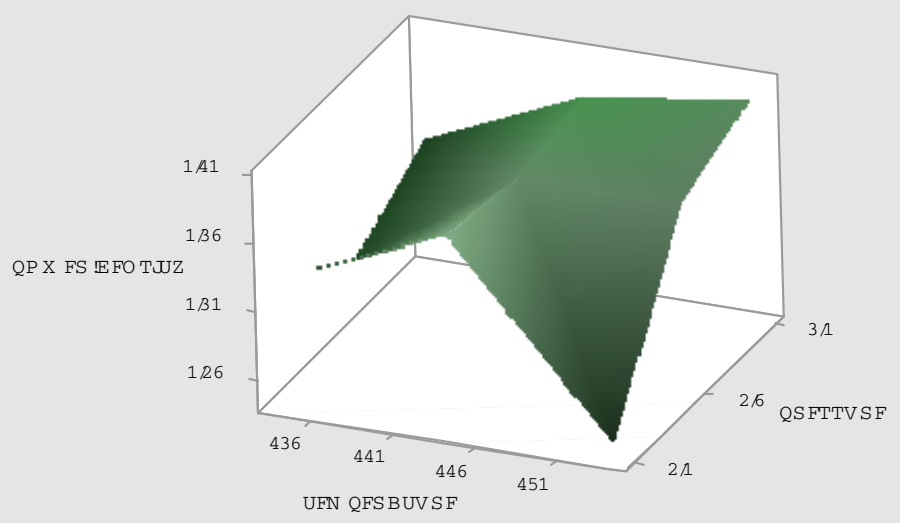

(b)

QP X FS EFO TUZ !wt!QSFTTV SF IBO E !TUP J/SBUIP

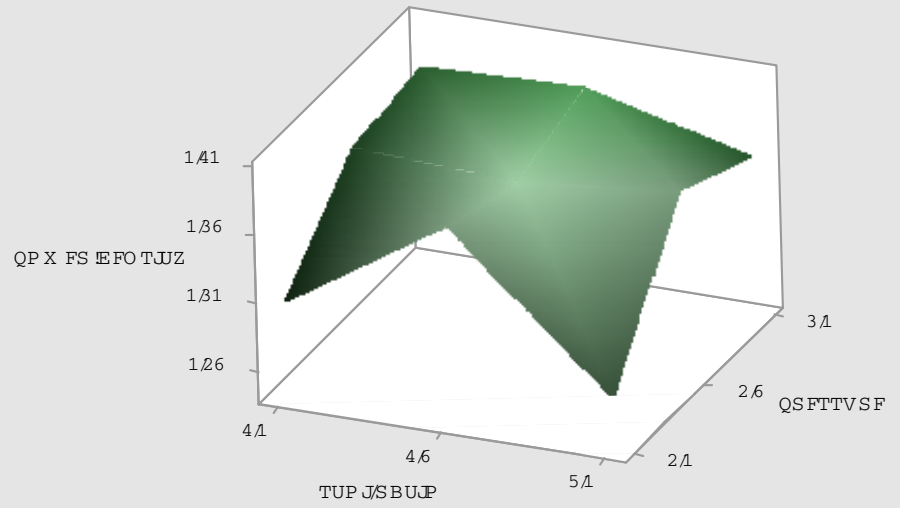

(c)

QP X FS EFO TUZ !Wt!UFN QFSBUV SF BO E !TUP J/SBUIP

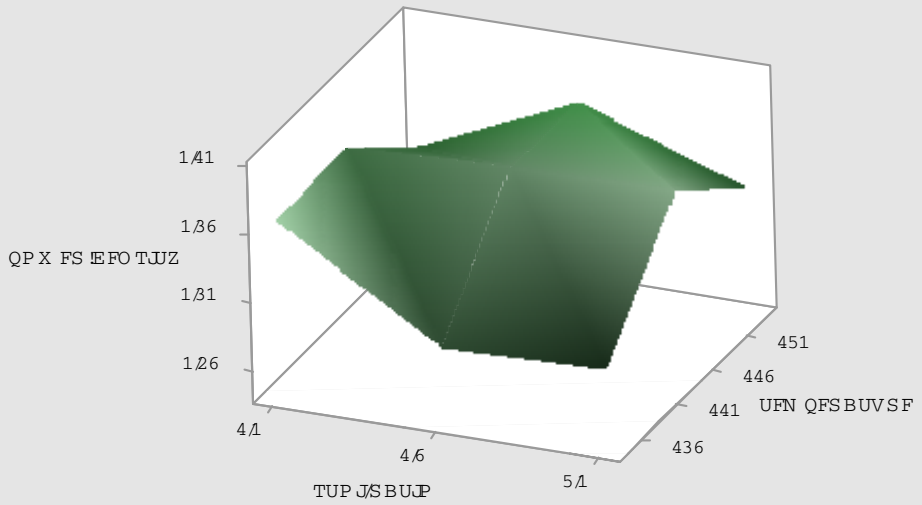

Fig. 2 Comparison of power density with various operating parameters of the $25 \mathrm{~cm}^{2}$ active area of interdigitated flow field. 


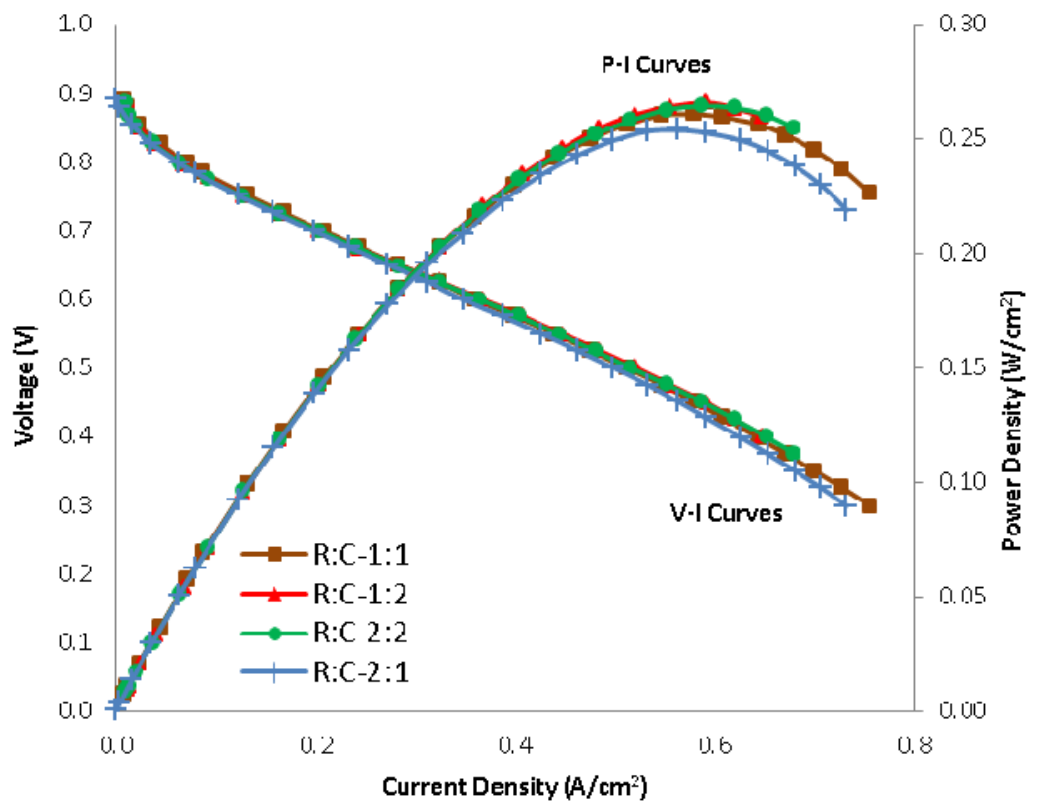

Fig. 3 Experimental performance of $25 \mathrm{~cm}^{2}$ active area of a PEM fuel cell with various rib-to-channel width ratios of interdigitated flow fields.

Table 5 Comparison of numerical and experimental results of $25 \mathrm{~cm}^{2}$ active area of PEM fuel cell

\begin{tabular}{|c|c|c|c|c|c|}
\hline Type & Values & $\mathrm{R}: \mathrm{C}$ & $\begin{array}{l}\text { Current density } \\
\left(\mathrm{A} / \mathrm{cm}^{2}\right)\end{array}$ & $\begin{array}{l}\text { Peak power density } \\
\left(\mathrm{W} / \mathrm{cm}^{2}\right)\end{array}$ & $\begin{array}{l}\text { Deviation of peak } \\
\text { power density (\%) }\end{array}$ \\
\hline \multirow{8}{*}{ 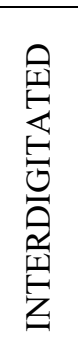 } & Numerical & \multirow{2}{*}{$1 \mathrm{X} 1$} & 0.574 & 0.272 & \multirow{2}{*}{4.2} \\
\hline & Experimental & & 0.58 & 0.261 & \\
\hline & Numerical & \multirow{2}{*}{$1 \times 2$} & 0.615 & 0.292 & \multirow{2}{*}{9.8} \\
\hline & Experimental & & 0.592 & 0.266 & \\
\hline & Numerical & \multirow{2}{*}{$2 \mathrm{X} 1$} & 0.627 & 0.267 & \multirow{2}{*}{5.1} \\
\hline & Experimental & & 0.564 & 0.254 & \\
\hline & Numerical & \multirow{2}{*}{$2 \times 2$} & 0.662 & 0.281 & \multirow{2}{*}{6.4} \\
\hline & Experimental & & 0.588 & 0.264 & \\
\hline
\end{tabular}

It was found that the results of numerical studies on interdigitated flow field deviated from the experimental results for $\mathrm{R}: \mathrm{C}$ ratios of $1: 1,1: 2,2: 1$, and $2: 2$ by $4.2 \%, 9.8 \%, 5.1 \%$, and $6.4 \%$, respectively.

\section{Conclusion}

The response surface methodology has been used for optimizing various operating parameters with the rib width-to-channel width ratios $(\mathrm{R}: \mathrm{C})$ of $1: 1,1: 2,2: 1$, and 2:2 of an interdigitated flow channel of $25 \mathrm{~cm}^{2}$ active area of the PEM fuel cell to find its optimum power density. Numerical results have been compared with the experimental validation of $25 \mathrm{~cm}^{2}$ active area of the PEM fuel cell. The interdigitated flow field with a R:C of 1:2 has produced the numerical and the experimental peak power density of $0.292 \mathrm{~W} / \mathrm{cm}^{2}$ and $0.266 \mathrm{~W} / \mathrm{cm}^{2}$, respectively, with a deviation of $9.8 \%$. Numerical studies on the performance of a PEM fuel cell with various rib-to-channel ratios of interdigitated flow fields can be done with reasonable confirmation.

\section{REFERENCES}

[1] Manso, A. P.,Garikano,X. \& Garmendia Mujika, M.(2012). Influence of geometric parameters of the flow fields on the performance of a PEM fuel cell. A review International Journal of Hydrogen Energy, 37 , 15256-15287. https://doi.org/10.1016/j.ijhydene.2012.07.076 
[2] Homayoon Kanani, Mehrzad Shams, Mohammadreza Hasheminasab, \& Ali Bozorgnezhad. (2015).

Model development and optimization of operating conditions to maximize PEM FUEL CELL performance by response surface methodology. Energy Conversion and Management, 93, 9-22. https://doi.org/10.1016/j.enconman.2014.12.093

[3] Imdat Taymaz and Elif Eker Kahveci. (2014). Experimental investigation on water and heat management in a PEM fuel cell using response surface methodology. International journal of hydrogen energy. 1 -9. https://doi.org/10.1016/j.ijhydene.2014.04.195

[4] Kanani, H, Shams, M, Hasheminasab, M \& Bozorgnezhad, A. (2015). Model development and optimization of operating conditions to maximize PEM FUEL CELL performance by response surface methodology. Energy Conversion and Management. 93, 9-22. https://doi.org/10.1016/j.enconman.2014.12.093

[5] Jaruwasupant, N \& Khunatorn, Y. (2011). Effects of difference flow channel designs on Proton Exchange Membrane Fuel Cell using 3-D Model. Energy procedia. 9, 326-337. https://doi.org/10.1016/j.egypro.2011.09.035

[6] Liu, H, Li, P, Juarez-Robles, D, Wang, K \& Hernandez-Guerrero, A. (2014). Experimental study and comparison of various designs of gas flow fields to PEM fuel cells and cell stack performance. Frontiers in Energy Research. 2, 2. https://doi.org/10.3389/fenrg.2014.00002

[7] Cheng, S-J, Miao, J-M \& Wu, S-J. ( 2012). Investigating the effects of operational factors on PEM FUEL CELL performance based on CFD simulations using a three-level full-factorial design. Renewable Energy. 39, 1, 250-260. https://doi.org/10.1016/j.renene.2011.08.009

[8] Iranzo, A, Muñoz, M, Rosa, F \& Pino, J. (2010). Numerical model for the performance prediction of a PEM fuel cell. Model results and experimental validation. International Journal of Hydrogen Energy. 35, 20, 11533-11550. https://doi.org/10.1016/j.ijhydene.2010.04.129

[9] Varadha Rajan Lakshminarayanan, Palaniswamy Karthikeyan, Charles Aswin and Deepindar Singh Charandeep Singh, (2015), Parametric analysis of proton exchange membrane Fuel cell (pemfc) performed by the taguchi method, Transactions of Famena,4, pp(79-88).

[10] Lakshminarayanan, V \& Karthikeyan, P. (2016). Optimization of Flow Channel Design and Operating Parameters on Proton Exchange Membrane Fuel Cell Using Mat lab. Periodica Polytechnica Chemical Engineering. Budapest Univ Technology Economics. 60, 3, 173-180. https://doi.org/10.3311/ppch.8461

[11] Karthikeyan, P, Velmurugan, P, George, AJ, Kumar, RR \& Vasanth, R. (2014). Experimental investigation on scaling and stacking up of proton exchange membrane fuel cells. International Journal of Hydrogen Energy. 39, 21, 11186-11195. https://doi.org/10.1016/j.ijhydene.2014.05.086

[12] Hyung Soon Kim, Seung Won Jeon, Dowon Cha, Yongchan Kim. (2016). Numerical analysis of a hightemperature proton exchange membrane fuel cell under humidified operation with stepwise reactant supply, International journal of hydrogen energy, 4 1, 13657 -13665. https://doi.org/10.1016/j.ijhydene.2016.05.296

[13] Behzad Osanloo, Akbar Mohammadi-Ahmar, Ali Solati. (2016). A numerical analysis on the effect of different architectures of membrane, CL and GDL layers on the power and reactant transportation in the square tubular PEMFC. International journal of hydrogen energy, 41, 25, 6, 10844-10853. https://doi.org/10.1016/j.ijhydene.2016.04.228

Submitted: $\quad 28.12 .2017$

Accepted: $\quad$ 13.3.2019
Dr. Lakshminarayanan Varadha Rajan Department of Mechanical Engineering, KGISL Institute of Technology

KG Campus, Saravanampatti

Coimbatore, Tamilnadu, India-641035

E-mail: lakshminarayanan.v@kgkite.ac.in

Dr. Velmurugan Pavanan

Department of Mechanical Engineering,

Malla Reddy College of Engineering,

Hyderabad, Telangana, India-500100,

E-mail: velmurugan_mech@mrce.in

Dr. Karthikeyan Palaniswamy

Department of Automobile Engineering,

PSG College of Technology, Peelamedu,

Coimbatore, Tamil Nadu, India - 641004.

E-mail: apkarthipsg@gmail.com 